\title{
Knowledge Creation and Commercialization Activities in Polish Public HEUs in the Area of Technical and Engineering Sciences
}

\author{
Urszula Sienkiewicz* and Izabela Kijeńska-Dąbrowska**
}
*Kredyt Bank S.A., ul. Kasprzaka 2/8, 01-211 Warsaw, Poland, <ula.sienkiewicz@gmail.com>
**The Information Processing Institute, Al. Niepodleglosci 188b, 00-608 Warsaw, Poland, <izabela.kijenska@opi.org.pl>

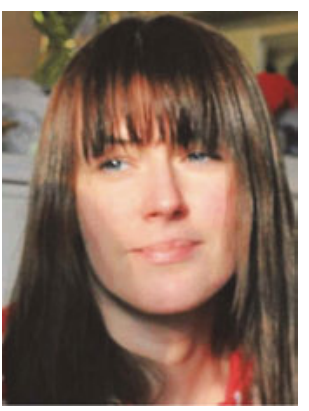

Urszula Sienkiewicz is a graduate of the Warsaw University of Technology, Faculty of Mathematics. From 2003-2012 she was an assistant at the Institute of Statistics and Demography at the Warsaw School of Economics, and from 2011-2012 a statistician at the Information Processing Institute. Currently she is an expert in credit risk analysis at a Polish bank. Her research interest is event history analysis.

Izabela Z. Kijeńska-Dąbrowska, PhD, is assistant professor at the Information Processing Institute, Warsaw, Poland. She completed her dissertation at the Warsaw School of Economics in 2010. Her recent research focuses on the Polish public research and development system. Her research interests concern aspects of regional and global innovation systems, development of new technologies, knowledge based economy; economic and technical problems of the knowledge and technology transfer from research institutions to industrial sectors.

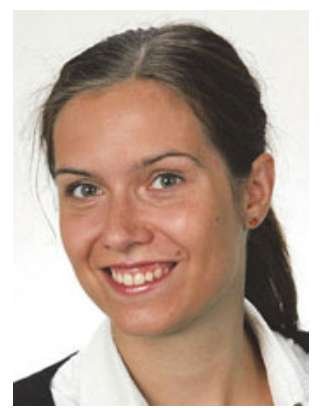

Sienkiewicz, Urszula, and Kijeńska-Dabrowska, Izabela. Knowledge Creation and Commercialization Activities in Polish Public HEUs in the Area of Technical and Engineering Sciences. Knowledge Organization. 40(2), 136-146. 17 references.

ABSTRACT: History of knowledge organization within higher education units (HEU) changes with respect to the idea of measuring activities of academia. The visible evolution of HEU's role in the economy is indicated in the performance of particular entities. Apart from the education activity, the production of new knowledge and publication of research results are no longer the sole aspects of HEU performance. The knowledge organization structure requires entrepreneurial behaviour from academia. In this paper, activities related to the commercialization of research results performed within HEU are analysed. The study concerns units in the area of technical and engineering studies and covers different aspects of research and development $(\mathrm{R} \& \mathrm{D})$ performance. There is a visible relation between the level of research/teaching team quality and publication activity and their economic influence. Statistical analyses conducted try to detect relations and/or influence of publications activity and researchers' level of education on commercialization benefits from research projects performance. HEU with a relatively high commercialization performance are those with the highest level of publication activity. At the same time, entities with a high number of well-experienced researchers are those with significant benefits from research projects. These results are important for the idea of measuring modern HEU performance with respect to traditional knowledge organization in academia.

Received 21 November 2012; Revised and Accepted 30 January 2013

\subsection{Introduction}

The commercialization of research and development "R\&D" results is a complex and dynamic process which starts from researcher's idea and develops through a very complex structure of environmental factors. In this paper, we try to explore the basic factors of knowledge organization having an influence on research commercialization.
The idea for these studies arises from the great pressure that is placed on research units and researchers to foster development of new ideas. These new ideas, in particularly in the area of technical and engineering sciences, are to be implemented in the real economy in the form of innovation. Recent publications (Hage and Meeus 2009; Viale and Etzkowitz 2010) underline the aspects of quality of research conducted within research entities that influence the 
developmental pace of modern economies. The necessity of a complex approach toward the interdisciplinarity activities of HEU, in particular technical universities and polytechnics, is also evident in analyses of knowledge organization (Silva and Ribeiro 2012).

There are a number of studies in literature showing the relationship between research commercialization performance and other characteristics of research units at the institutional (Owen-Smith and Powell 2003; Foltz 2007) and individual level (Meyer 2006; Agrawal and Anderson 2002; O'Shea et al. 2005). The relationship at the institutional level shows that factors such as publishing activity, number of researchers, and research funding are related to patenting performance (Wong and Singh 2010). In the literature, there are also findings on factors having an impact on publication activity such as internationalization (Abramo, D'Angelo, and Solazzi 2011) and individual institutions, individual disciplinary areas within each institution and individual organization units (faculties, departments, etc.) within each area (Abramo, D'Angelo, and Pugini 2008), together with the size of faculty's research budget or research infrastructure (Baskurt 2011). The main emphasis is placed on publishing activity. It draws a distinction between quantity of publications and quality of publications and their distinct influence on commercialization activity (Wong and Singh 2010). The recent research (Moneda Corrochano, López-Huertas, and Jiménez-Contreras 2012) gives also evidence that changes of the number and quality of papers might also be influenced by the number of sophisticated co-authors undersigned. While the total value of publication productivity might decrease, its quality rises with an increase in papers published in ISI journals. There is also evidence for differences in influence on patenting and revenue from sale of R\&D. As Geuna and Nesta (2006) show, university licensing is not profitable for most universities, although some do succeed in attracting substantial additional revenues.

In this paper, we examine the impact of the quality of the scientific research and sources of funds for research on the tangible results of scientific activity, i.e. the number of patents generated by research and revenues from the sale of R\&D results. For the explanatory variables, we use information about publication activity, number of unit employees, funds for research, and the quality of the university to which the unit belongs as stated by the Hirsch index.

\subsection{Data origin and representativeness}

Data comes from the Information Processing Institute and Research Unit Questionnaire (detailed information on the website http://nauka-polska.pl/shtml/ankieta/ankieta_jed _informacje.shtml), which collects data about research unit performance. The Research Unit Questionnaire is a report which units are required to submit annually in order to apply for grants for basic statutory science funds. The data used in the study concerns units in the area of technical and engineering studies and covers different aspects of research and development performance.

\subsection{Analysis methods and variables}

\subsection{Dependent variables}

In order to analyze the commercialization of research results, we analysed patents and benefits from research performance in two ways. Firstly, analysis concerns only the dichotomous information, e.g. whether the unit is patenting or not and whether the unit is commercializing or not. Then the relationship between the quantity of information about the level of publications and patents as well as the level of publication and benefits is explored. To test the relationship in question, nonparametric test of distribution equality, logistic regression, and correlation analysis methods were used.

\subsubsection{Patent performance}

Our indicator of entity patent output in the database is based on information about the number of patents issued in 2005 year. The information is divided into the number of domestic patents and foreign patents. According to foreign patents, more than $94 \%$ of entities did not have any patent granted abroad. Therefore all the conclusions in this paper involve only the patents granted in Poland.

\subsubsection{Commercialization performance}

The second dependent variable considered was information about commercialization expressed by revenue from $\mathrm{R} \& \mathrm{D}$ results sales. The revenue considered is in total values and then divided into revenues from domestic and foreign sources.

\subsection{Explanatory variables}

As explanatory variables, information about publication activity, number of unit employees, quantity of funds for research activity, and quality of the university to which the unit belongs, as stated by the Hirsch index, are used.

\subsubsection{Publication activity}

The publication activity was divided into three stages. First the number of all papers published was analysed. Then it was divided into two categories-papers pub- 
lished in scientific domestic journals and papers published in scientific foreign journals.

\subsubsection{Number of researchers}

This characteristic of research unit was divided into the number of employees with $\mathrm{PhDs}$ or higher scientific degrees and the number of employees without scientific degrees.

\subsubsection{Funds for research}

In the database, there is information about sources of funds for research in a total amount which is the total output from R\&D activity (including output from the sale of $\mathrm{R} \& \mathrm{D}$ results) and information about statutory budget.

\subsubsection{Quality of university}

The quality of university is represented by the Hirsch Index for universities during period $2000-2008$. The $b$ index is defined as number of papers with citations higher or equal to $h$ (Hirsch 2005). For university comparison purposes, we used a modification of the Hirsch Index proposed by Molinari and Molinari (2008). This modification takes into account number of publications of the university.

The Hirsch index was calculated by Kierzek (2008) based on the databases from Institute of Scientific Information (Philadelphia, USA): Science Citation Index Expanded (SCI-EXPANDED. 1973 - present), Social Sciences Citation Index (SSCI, 1973 - present), and Arts \& Humanities Citation Index (A\&HCI, 1975 - present) (www.ibch.poznan.pl/PI/Sprawy_Nauki/).

\subsection{Results}

Descriptive statistics show that distribution of patenting and commercialization activity are both very right skewed (the skewness coefficient is positive and high), which means that the level of patenting and commercializing research result in Poland is lower than the average. Moreover, right skewness is a characteristic mark for all units under consideration.

The analysis of the influence of a unit's characteristics on the propensity to patenting and commercializing is shown in Table 3 and Table 4. Firstly, the distinction between distribution of the characteristics among those who patent and those who are not using Kolmogorov-Smirnov statistic, which measures the highest difference between cumulative distribution functions, is tested. Then the level of influence on the propensity to patenting and commercializing is explored. This level is expressed by odds ratios which can be interpreted as percentage increase in units probability to patenting or commercializing produced by an increase in a characteristic's value by particular unit. To show the highest influence, the Gini statistic is calculated; this expresses the discriminatory power of variable. The Gini statistic is calculated as the area under ROC (receiver operating curve) minus 0.5 . The ROC curve is created for ordered variable values and the corresponding percentage of units which experienced the event under consideration. The higher the Gini is, the higher is the discriminatory power of the variable. This means that the high percentage of units did not experience the activity under consideration, which corresponds to the lower values of the variable. For instance, the increase of one research employee with a PhD or higher degree increases the chance for patenting by $1.2 \%$.

According to the patenting activity, the statistically significant differences between distributions of the characteristics occur for publications activity, number of employees, and funds for research. Based on the odds ratios, all the significant characteristics have positive influence. Referring to total patenting activity, there is a significant influence of all type of publications. A slightly different situation can be observed for domestic patenting activity. The statistically significant influence is only for total publications number and domestic publications number. There is no significant influence for scientific publications.

An entirely different situation emerges for commercialization activity. There is a common characteristic of universities which has statistically significant influence for all three types of commercialization-the Hirsch index and modification of the Hirsch index. In the case of revenue from abroad, there are several statistically significant variables, such as the number of employees and the number of publications. However, taking into account publications in contrast to patent activity, the signification is given for the number of scientific publications. Together with Hirsch index signification, this is a clear illustration of the strong influence of university quality on commercialization activity.

Table 5 and Table 6 present the Pearson correlation coefficients between explanatory variables and patenting and commercialization. They are calculated only for those units with patenting and commercialization activity. This statistics show there is no linear relation between explanatory conducted and dependent variables. In order to explore existence of any relationship, the one way analysis of variance is conducted (Table 7 and Table 8). The explanatory variables are divided into four groups using quartiles values. Then the influence of every single unit's characteristic on the group means is tested. In case the assumption of variance homogeneity is not proved, the Welch analysis of variance was conducted (in Table 7 and Table 8, such vari- 
U. Sienkiewicz, and I. Kijeńska-Dąbrowska. Knowledge Creation and Commercialization Activities in Polish Public HEUs

\begin{tabular}{|c|c|c|c|c|c|c|c|}
\hline Variable Name & Mean & $\begin{array}{l}\text { Coeff of } \\
\text { Variation } \\
\text { (\%) }\end{array}$ & $\begin{array}{l}\text { Lower } \\
\text { Quartile }\end{array}$ & Median & $\begin{array}{l}\text { Upper } \\
\text { Quartile }\end{array}$ & Skewness & Maximum \\
\hline All patents (\#) & 1,79 & 153,46 & 0,00 & 1,00 & 3,00 & 2,35 & 13,00 \\
\hline Domestic patent (\#) & 1,70 & 157,42 & 0,00 & 1,00 & 2,00 & 2,50 & 13,00 \\
\hline Foreign patents $(\#)$ & 0,10 & 458,64 & 0,00 & 0,00 & 0,00 & 5,16 & 3,00 \\
\hline All publication (\#) & 159,44 & 77,87 & 76,00 & 136,00 & 212,00 & 1,88 & 716,00 \\
\hline Domestic publications (\#) & 125,03 & 86,48 & 51,00 & 106,00 & 167,00 & 2,15 & 637,00 \\
\hline Scientific publications (\#) & 34,65 & 169,78 & 4,00 & 12,00 & 38,00 & 2,94 & 303,00 \\
\hline R\&D employees (\#) & 116,89 & 54,81 & 76,00 & 103,00 & 144,00 & 1,49 & 404,25 \\
\hline Employees without sci, degree (\#) & 31,41 & 86,13 & 11,00 & 28,00 & 43,00 & 1,78 & 157,00 \\
\hline Employees with $\mathrm{PhD}$ or higher (\#) & 85,48 & 56,21 & 53,00 & 76,00 & 110,00 & 1,09 & 264,25 \\
\hline $\begin{array}{l}\text { Total output from R\&D activity } \\
\text { (ths. PLN) }\end{array}$ & 4411,20 & 105,53 & 882,98 & 2980,87 & 6125,24 & 1,69 & 21030,55 \\
\hline Statutory Budget (ths. PLN) & 3002,93 & 110,40 & 709,94 & 1793,05 & 4028,10 & 1,90 & 17537,62 \\
\hline Sale of R\&D Results (ths. PLN) & 439,58 & 218,05 & 0,00 & 21,76 & 505,31 & 4,12 & 7172,64 \\
\hline $\begin{array}{l}\text { Sale of R\&D Results, Domestic } \\
\text { (ths. PLN) }\end{array}$ & 264,33 & 258,30 & 0,00 & 9,19 & 209,79 & 4,59 & 4984,40 \\
\hline $\begin{array}{l}\text { Sale of R\&D Results, Aborad (ths. } \\
\text { PLN) }\end{array}$ & 175,26 & 350,94 & 0,00 & 0,00 & 37,12 & 7,70 & 6368,80 \\
\hline Citations in 2004 year $(\#)$ & 2168,22 & 103,27 & 480,00 & 2142,00 & 3193,00 & 3,17 & 15853,00 \\
\hline Citations in 2005 year (\#) & 2739,76 & 103,26 & 607,00 & 2711,00 & 3928,00 & 3,01 & 19183,00 \\
\hline Hirsch index & 30,68 & 38,80 & 22,50 & 31,00 & 34,50 & 1,11 & 77,00 \\
\hline Modified Hirsch index & 1,38 & 16,87 & 1,21 & 1,34 & 1,62 & 0,32 & 2,09 \\
\hline
\end{tabular}

Table 1. Descriptive statistics

ables are marked with "w"). The results of the analysis of variance show, for instance in case of number of scientific publications, there is statistically significant dependency between those publications and number of patents. In other words, we can say that the number of scientific publications differentiates the average number of patents.

The statistics show that not all the variables which had an influence on patenting or commercialization activity have an influence on the level of such activity. In the case of patenting activity, those variables are domestic publications and total science funds. Moreover we can observe that the direction of this influence is not always constant. For instance, the increase of total number of R\&D employees causes an increase of the average number of patents, but only for the three first groups. In the last group, which is the group of units with the highest number of employees, the average number of patents is lower than in the former groups. This situation occurs for both total number of patents and number of domestic patents.

According to revenue from the sale of $\mathrm{R} \& \mathrm{D}$ results, there are only several variables for which we saw statistically significant results and what is more, for the majority of this the significance is at the 0.1 level. Additionally, for most of the significant variables, the influence direction is not constant, in particular according to characteristics describing university quality such as citation number and Hirsch index.

\subsection{Conclusions}

The analyses conducted show that there are different factors influencing patenting performance and research result sale performance. As far as patenting is concerned, the analysis indicates that this activity is influenced by the number of publications, most of all the domestic publications; the number of employees with scientific degrees, $\mathrm{PhD}$ or higher; and funding for science (including both total and statutory funds). In the case of revenue from the sale, the greater importance is found for the characteristics defining the quality of the scientific environment of the individual and quality of the entity, as expressed in the number of scientific publications published in international scientific journals. Such characteristics as number of publications, including in particular the number of domestic publications, does not skew the sale of research results in any of the three considered types of revenue (total, do- 


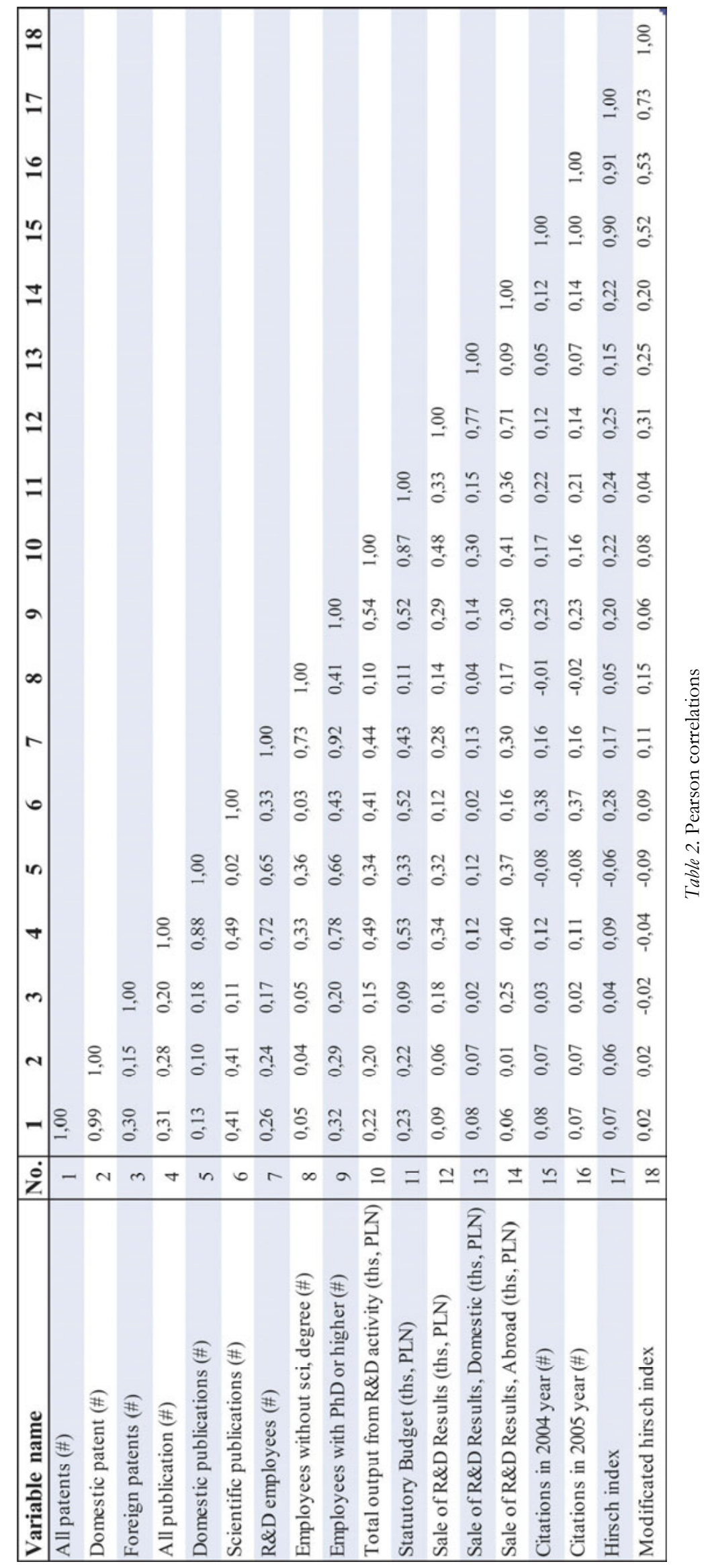


U. Sienkiewicz, and I. Kijeńska-Dąbrowska. Knowledge Creation and Commercialization Activities in Polish Public HEUs

\begin{tabular}{|c|c|c|c|c|c|c|c|c|c|c|}
\hline \multirow{2}{*}{ Variable name } & \multicolumn{5}{|c|}{ Patents, Total } & \multicolumn{5}{|c|}{ Patents, Domestic } \\
\hline & K-S & & Odds Ratio & & Gini & K-S & & Odds Ratio & & Gini \\
\hline \multirow{3}{*}{$\begin{array}{l}\text { All publication (\#) } \\
\text { Domestic publications (\#) } \\
\text { Scientific publications (\#) }\end{array}$} & 0,353 & * & 1,006468 & * & 0,397 & 0,336 & * & 1,004583 & * & 0,369 \\
\hline & 0,271 & $* *$ & 1,006408 & $*$ & 0,334 & 0,254 & $* *$ & 1,004253 & $* *$ & 0,306 \\
\hline & 0,298 & * & 1,005696 & $* *$ & 0,301 & 0,283 & & 1,005155 & & 0,283 \\
\hline \multirow{3}{*}{$\begin{array}{l}\text { R\&D employees (\#) } \\
\text { Employees without sci. degree (\#) } \\
\text { Employees with PhD or higher (\#) }\end{array}$} & 0,264 & $* *$ & 1,006660 & $* *$ & 0,269 & 0,252 & $* *$ & 1,004708 & $* *$ & 0,240 \\
\hline & 0,186 & & 0,999205 & & 0,030 & 0,197 & & 0,996535 & & 0,057 \\
\hline & 0,268 & $* *$ & 1,012457 & $*$ & 0,325 & 0,259 & $* *$ & 1,009812 & $* *$ & 0,298 \\
\hline \multirow{2}{*}{$\begin{array}{l}\text { Total output from R\&D activity } \\
\text { (ths. PLN) } \\
\text { Statutory Budget (ths. PLN) }\end{array}$} & 0,376 & * & 1,000103 & * & 0,391 & 0,364 & * & 1,000077 & $* *$ & 0,363 \\
\hline & 0,338 & * & 1,000131 & * & 0,357 & 0,321 & * & 1,000099 & $* *$ & 0,332 \\
\hline \multirow{2}{*}{$\begin{array}{l}\text { Sale of R\&D Results, Domestic } \\
\text { (ths. PLN) } \\
\text { Sale of R\&D Results, Abroad (ths. } \\
\text { PLN) }\end{array}$} & 0,297 & & 1,000206 & & 0,239 & 0,280 & & 1,000168 & & 0,241 \\
\hline & 0,189 & & 1,001133 & & 0,161 & 0,167 & & 1,000034 & & 0,129 \\
\hline \multirow{3}{*}{$\begin{array}{l}\text { Citations in } 2004 \text { year (\#) } \\
\text { Citations in } 2005 \text { year }(\#) \\
\text { Hirsch index }\end{array}$} & 0,191 & & 1,000080 & & 0,181 & 0,175 & & 1,000064 & & 0,153 \\
\hline & 0,191 & & 1,000057 & & 0,180 & 0,175 & & 1,000043 & & 0,151 \\
\hline & 0,191 & & 1,015921 & & 0,169 & 0,175 & & 1,011511 & & 0,140 \\
\hline Modified Hirsch index & 0,097 & & 2,062918 & & 0,088 & 0,090 & & 1,692073 & & 0,068 \\
\hline
\end{tabular}

Table 3. Kolmogorov-Smirnov statistics and logistic regression results - Patents

\begin{tabular}{|c|c|c|c|c|c|c|c|c|c|c|c|c|c|c|c|}
\hline \multirow{2}{*}{ Variable name } & \multicolumn{5}{|c|}{ Revenue from R\&D, Total } & \multicolumn{5}{|c|}{ Revenue from R\&D, Domestic } & \multicolumn{5}{|c|}{ Revenue from R\&D, Abroad } \\
\hline & K-S & & Odds Ratio & & Gini & K-S & & Odds Ratio & & Gini & K-S & & Odds Ratio & & Gini \\
\hline All patents (\#) & 0,188 & & 1,192238 & & 0,228 & 0,186 & & 1,138484 & & 0,215 & 0,174 & & 1,086160 & & 0,165 \\
\hline $\begin{array}{l}\text { Domestic patent } \\
(\#)\end{array}$ & 0,179 & & 1,214503 & & 0,227 & 0,173 & & 1,152158 & & 0,217 & 0,149 & & 1,070405 & & 0,137 \\
\hline Foreign patents (\#) & 0,030 & & 1,044110 & & 0,029 & 0,015 & & 0,877415 & & 0,015 & 0,131 & & 2,187855 & & 0,129 \\
\hline All publication (\#) & 0,245 & & 1,001893 & & 0,217 & 0,206 & & 1,001665 & & 0,179 & 0,285 & $* *$ & 1,003718 & $* *$ & 0,334 \\
\hline $\begin{array}{l}\text { Domestic publica- } \\
\text { tions (\#) }\end{array}$ & 0,129 & & 1,000564 & & 0,086 & 0,186 & & 1,001598 & & 0,174 & 0,172 & & 1,002536 & & 0,134 \\
\hline $\begin{array}{l}\text { Scientific publica- } \\
\text { tions (\#) }\end{array}$ & 0,164 & & 1,007735 & & 0,139 & 0,087 & & 1,001811 & & 0,075 & 0,369 & $*$ & 1,007474 & $* *$ & 0,386 \\
\hline $\begin{array}{l}\text { R\&D employees } \\
(\#)\end{array}$ & 0,226 & & 1,003923 & & 0,214 & 0,181 & & 1,003103 & & 0,157 & 0,292 & $* *$ & 1,005664 & $* *$ & 0,285 \\
\hline $\begin{array}{l}\text { Employees without } \\
\text { sci. degree }(\#)\end{array}$ & 0,096 & & 1,001145 & & 0,034 & 0,101 & & 1,001897 & & 0,031 & 0,080 & & 0,999391 & & $-0,004$ \\
\hline $\begin{array}{l}\text { Employees with } \\
\text { PhD or higher (\#) }\end{array}$ & 0,294 & * & 1,006595 & $* *$ & 0,248 & 0,205 & & 1,004886 & & 0,172 & 0,346 & $*$ & 1,010473 & * & 0,347 \\
\hline $\begin{array}{l}\text { Total output from } \\
\text { R\&D activity (ths. } \\
\text { PLN) }\end{array}$ & 0,312 & * & 1,000073 & $* *$ & 0,290 & 0,214 & & 1,000045 & & 0,198 & 0,527 & $*$ & 1,000193 & $*$ & 0,583 \\
\hline $\begin{array}{l}\text { Statutory Budget } \\
\text { (ths. PLN) }\end{array}$ & 0,241 & & 1,000041 & & 0,189 & 0,195 & & 1,000012 & & 0,163 & 0,481 & $*$ & 1,000180 & $*$ & 0,475 \\
\hline $\begin{array}{l}\text { Sale of R\&D Re- } \\
\text { sults, Domestic } \\
\text { (ths. PLN) }\end{array}$ & 0,910 & $*$ & 1,492514 & * & 0,910 & & & & & & 0,489 & * & 1,001188 & $*$ & 0,539 \\
\hline $\begin{array}{l}\text { Sale of R\&D Re- } \\
\text { sults, Abroad (ths. } \\
\text { PLN) }\end{array}$ & 0,449 & & 1,177181 & & 0,449 & 0,282 & $*$ & 1,001279 & $* *$ & 0,258 & & & & & \\
\hline $\begin{array}{l}\text { Citations in } 2004 \\
\text { year (\#) }\end{array}$ & 0,213 & & 1,000195 & & 0,143 & 0,209 & & 1,000107 & & 0,119 & 0,203 & & 1,000070 & & 0,148 \\
\hline $\begin{array}{l}\text { Citations in } 2005 \\
\text { year (\#) }\end{array}$ & 0,290 & $* *$ & 1,000199 & $* *$ & 0,229 & 0,277 & & 1,000114 & & 0,209 & 0,226 & & 1,000071 & & 0,226 \\
\hline Hirsch index & 0,389 & $*$ & 1,048751 & $* *$ & 0,261 & 0,267 & $* *$ & 1,030471 & $* *$ & 0,173 & 0,365 & $*$ & 1,040889 & $* *$ & 0,335 \\
\hline $\begin{array}{l}\text { Modified Hirsch } \\
\text { index }\end{array}$ & 0,409 & $*$ & 18,709834 & * & 0,366 & 0,285 & $* *$ & 6,349258 & $* *$ & 0,237 & 0,397 & $*$ & 22,180335 & $*$ & 0,424 \\
\hline
\end{tabular}







U. Sienkiewicz, and I. Kijeńska-Dąbrowska. Knowledge Creation and Commercialization Activities in Polish Public HEUs

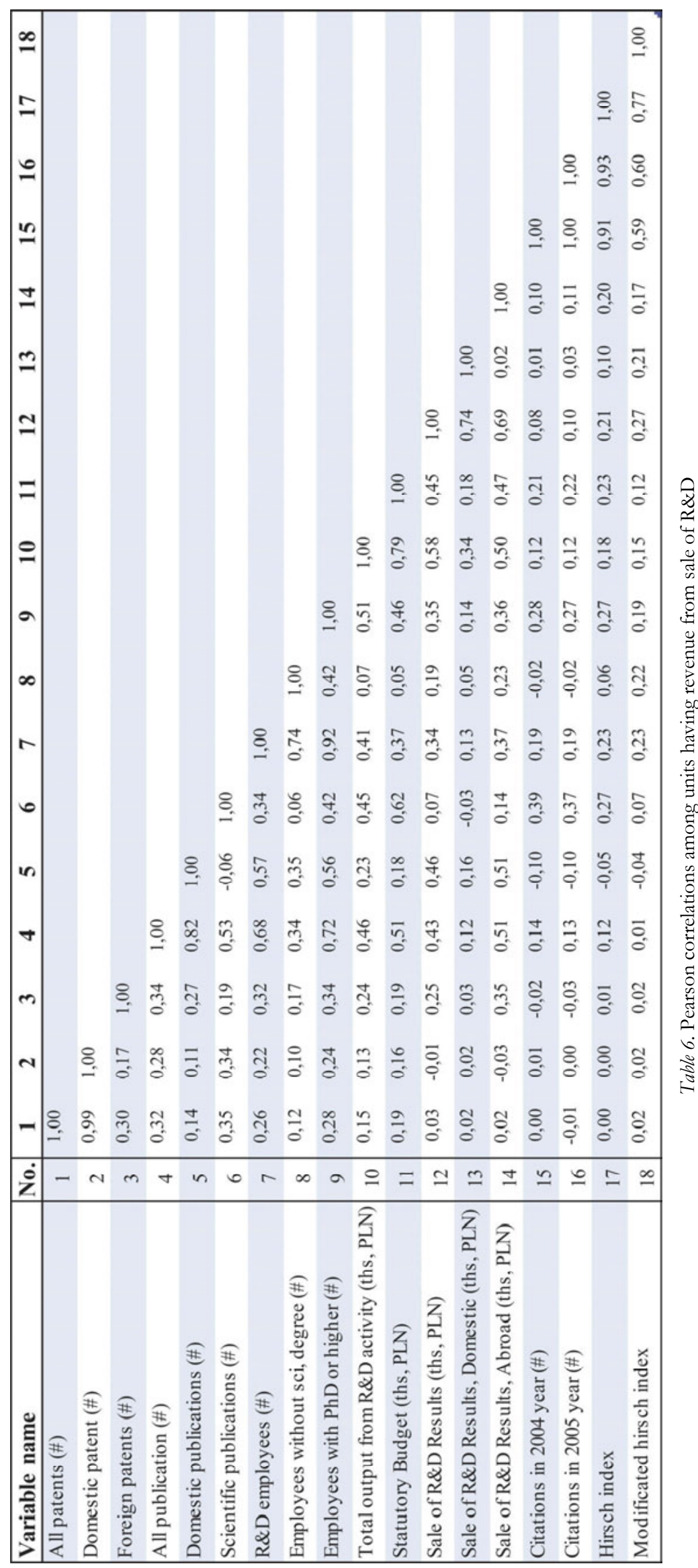




\begin{tabular}{|c|c|c|c|c|c|c|c|c|c|c|c|c|c|}
\hline \multirow{4}{*}{$\begin{array}{l}\text { Variable name } \\
\text { Domestic patent (\#) }\end{array}$} & \multicolumn{6}{|c|}{ Patents, Total } & \multicolumn{7}{|c|}{ Patents, Domestic } \\
\hline & \multirow{2}{*}{\multicolumn{2}{|c|}{ F Statistic }} & \multicolumn{4}{|c|}{ Group means } & \multirow{2}{*}{\multicolumn{3}{|c|}{ F Statistic }} & \multicolumn{4}{|c|}{ Group means } \\
\hline & & & 1 & 2 & 3 & 4 & & & & 1 & 2 & 3 & 4 \\
\hline & 55,7 & $\mathrm{~W} \quad *$ & 1,18 & 2,05 & 3,58 & 8,27 & 27,44 & $\mathrm{w}$ & $*$ & 1,00 & 2,00 & 3,10 & 7,69 \\
\hline All publication (\#) & 3,36 & $\mathrm{~W} \quad * *$ & 2,21 & 3,00 & 4,05 & 4,50 & 3,04 & $\mathrm{w}$ & ** & 2,11 & 3,00 & 3,75 & 4,35 \\
\hline Domestic publications (\#) & 0,48 & & 2,95 & 3,81 & 3,88 & 3,06 & 0,37 & & & 2,89 & 3,67 & 3,63 & 2,94 \\
\hline Scientific publications (\#) & 2,69 & $\mathrm{~W} \quad * *$ & 2,81 & 2,94 & 2,37 & 5,72 & 2,84 & $\mathrm{w}$ & ** & 2,57 & 2,88 & 2,26 & 5,56 \\
\hline R\&D employees (\#) & 5,62 & $\mathrm{~W} \quad *$ & 1,90 & 3,50 & 4,37 & 4,06 & 5,53 & $\mathrm{w}$ & $*$ & 1,80 & 3,35 & 4,16 & 3,94 \\
\hline $\begin{array}{l}\text { Employees without sci, de- } \\
\text { gree (\#) }\end{array}$ & 0,97 & & 3,89 & 2,70 & 3,00 & 4,11 & 0,94 & & & 3,53 & 2,89 & 2,63 & 4,11 \\
\hline $\begin{array}{l}\text { Employees with PhD or } \\
\text { higher (\#) }\end{array}$ & 5,68 & $\mathrm{~W} *$ & 1,95 & 3,44 & 3,89 & 4,56 & 3,20 & & $* *$ & 1,85 & 3,44 & 3,33 & 4,67 \\
\hline $\begin{array}{l}\text { Total output from R\&D activ- } \\
\text { ity (ths, PLN) }\end{array}$ & 1,31 & & 2,37 & 3,68 & 3,42 & 4,28 & 1,50 & & & 2,26 & 3,61 & 3,11 & 4,22 \\
\hline Statutory Budget (ths, PLN) & 2,20 & $* *$ & 2,47 & 2,95 & 3,53 & 4,83 & 2,59 & & $* *$ & 2,37 & 2,67 & 3,37 & 4,78 \\
\hline $\begin{array}{l}\text { Sale of R\&D Results, Do- } \\
\text { mestic (ths, PLN) }\end{array}$ & 0,54 & & 3,15 & 4,33 & 3,05 & 3,61 & 0,74 & & & 2,88 & 4,36 & 3,00 & 3,50 \\
\hline $\begin{array}{l}\text { Sale of R\&D Results, Abroad } \\
\text { (ths, PLN) }\end{array}$ & 0,30 & & 3,37 & . & 2,88 & 3,83 & 0,20 & & & 3,27 & . & 2,71 & 3,56 \\
\hline Citations in 2004 year (\#) & 0,21 & & 3,29 & 3,47 & 3,93 & 3,08 & 0,15 & & & 3,18 & 3,11 & 3,73 & 3,25 \\
\hline Citations in 2005 year (\#) & 0,82 & & 3,29 & 2,94 & 4,41 & 3,08 & 0,51 & & & 3,18 & 2,76 & 4,00 & 3,25 \\
\hline Hirsch index & 0,12 & & 3,29 & 3,75 & 3,56 & 3,15 & 0,02 & & & 3,18 & 3,31 & 3,39 & 3,33 \\
\hline Modified Hirsch index & 0,73 & & 3,36 & 3,39 & 4,50 & 2,82 & 0,84 & & & 3,04 & 3,39 & 4,42 & 2,75 \\
\hline
\end{tabular}

Table 7. Analysis of variance results for patenting units

mestic, and abroad). In addition, studies have proven that, even if there exists a factor which skews the fact of patenting or sale, such as the number of publications, there might not be a conclusion that the increase in the number of publications will increase the number of patents or increase the revenue from the sale. Most such variables do not have an impact on the level of the studied phenomenon, or the influence is not linear. Finally, it is vital to understand the processes of knowledge creation and commercialization of research results with respect to the overall activity of HEU. Knowledge creation in the academic environment might either arise from an idea of the researcher or evolve from the particular market (economy) need.

The results of the analysis indicate that none of the investigated mechanisms have an influence on the commercialization of R\&D results process. This might be caused by the dual nature of the research commercialization process. From one perspective, this process starts with the researcher's idea and then develops through research and results in patent or in direct commercial application. In this case, we can expect that the number of patents or the amount of revenue from the sale of research results may be less affected by the quality of the research unit and more affected by the quality of individuals - the researchers. On the other side, the process can be considered contrary, starting from the demand for specific technology. An entity requiring particular technology needs to select the research units, as guided by certain criteria. This can enhance research units with better quality and more experienced researchers as favoured by enterprises. Finally, it causes stronger relationships between research unit quality and commercialization of $\mathrm{R} \& \mathrm{D}$ results. However, answering these research questions requires analysis at the individual level-the researcher (demand), as well as at recipients of technology and knowledge (supply).

\section{References}

Abramo, Giovanni, D'Angelo, Ciriaco Andrea and Pugini, Fabio. 2008. The measurment of Italian universities' research productivity by a non parametric-bibliometric methodology. Scientometrics 76: 225-44.

Abramo, Giovanni, D’Angelo, Ciriaco Andrea, C.A., Solazzi Marco. 2011. The relationship between scientists' 


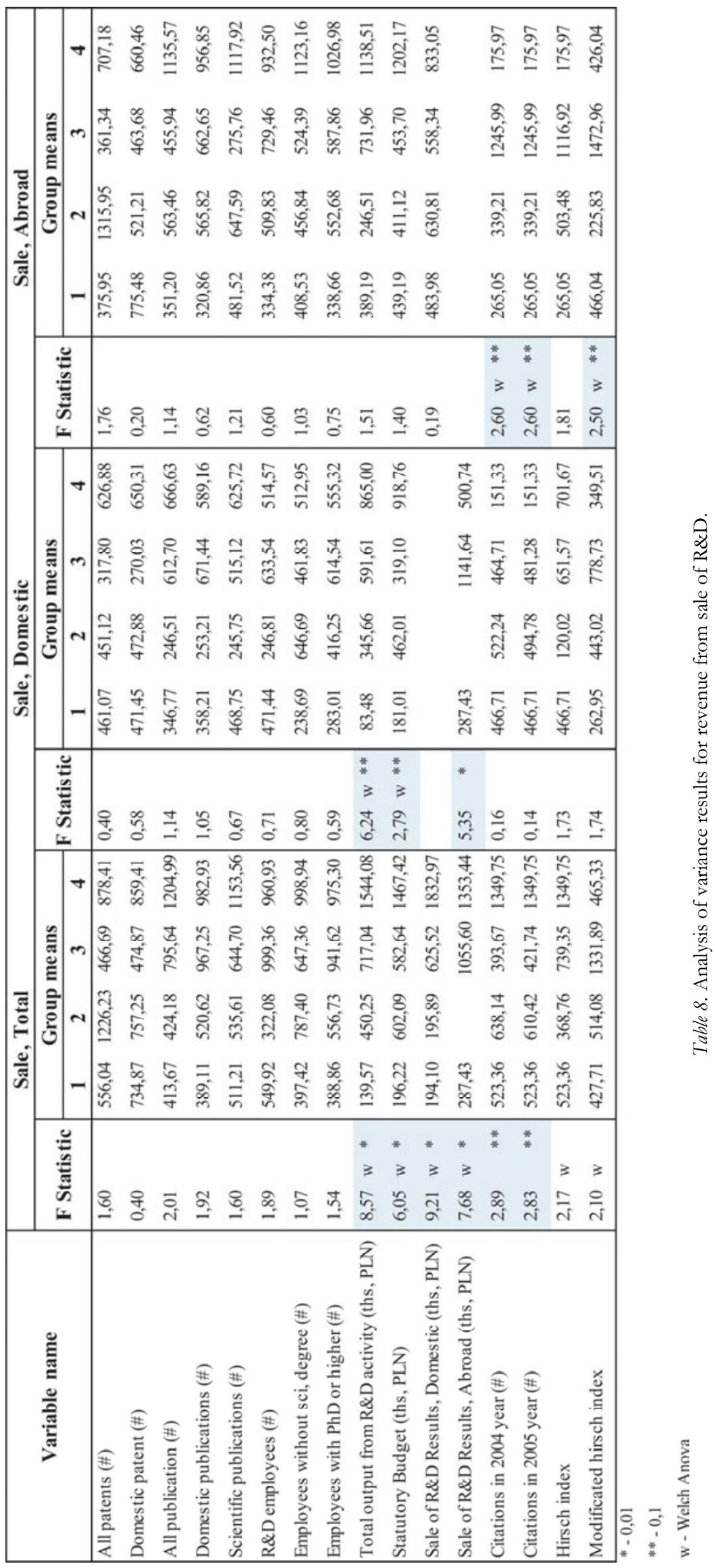


research performance and the degree of internationalization of their research. Scientometrics 86: 629-43.

Agrawal, Ajay and Anderson, Rebecca. 2002. Putting patents in context: Exploring knowledge transfer from MIT. Management science 4: p. 44-60.

Baskurt, Oguz K. 2011. Time series analysis of publication counts of a university: what are the implications? Scientometrics 86: 645-56.

Foltz, Jeremy D., Barham, Bradford L. and Kim, Kwansoo. 2007. Synergies of trade-offs in university life sciences research. American journal of agricultural economics 89: 353-67.

Geuna, Aldo and Nesta, Lionel J.J. 2006. University patenting and its effects on academic research: The emerging European evidence. Research policy 35: 790-807.

Hage, Jerald and Meeus, Marius. 2009. Innovation, science and institutional change, a research handbook. New York: Oxford University Press.

Hirsch, Jorge E. 2005. An index to quantify an individuals scientific research output. PNAS 102: 16569-72.

Kierzek, Ryszard. 2008. Polska nauka w indeksie Hirsch. Sprany Nauki 137 (29).

Meyer Martin. 2006. Are patenting scientists the better scholars? An exploratory comparison of inventorauthors with their non-inventing peers in nano-science and technology. Research policy 35: 1646-62.
Molinari, Jean-François and Molinari, Alain. 2008. A new methodology for ranking scientific institutions. Scientometrics. 75: 163-74.

Moneda Corrochano, Mercedes, López-Huertas María José and Jiménez-Contreras Evaristo. 2012. Spanish research in knowledge organization (2002-2010). Knowledge organization 40: 28-41.

O’Shea, Rory P., Allen, Thomas J., Chevalier, Arnaud and Roche, Frank. 2005. Entrepreneurial orientation, technology transfer and spinoff performance of U.S. universities. Research Policy 34: 443-57.

Owen-Smith, Jason and Powell, Walter W. 2003. The expanding role of university patenting in the life sciences: Assesing the importance of experience and connectivity. Research policy 32: 1695-711.

Silva, Armando Malheiro and Ribeiro, Fernanda. 2012. Documentation / information and their paradigms: Characterization and importance in research, education, and professional practice. Knowledge organization 39: 111-24.

Viale, Riccardo and Etzkowitz, Henry. 2010. The capitalization of knowledge: A triple belix of university-industrygovernment. Cheltenham, UK: Edward Elgar.

Wong, Poh Kam and Singh, Annette. 2010. University patenting activities and their link to the quantity of scientific publications. Scientometrics 83: 271-94. 